\title{
Faktor-Faktor Predisposisi yang berhubungan dengan Pencegahan DBD di Tanjung Basung Wilayah Kerja Puskesmas Pasar Usang
}

\author{
Yulia M. Nur ${ }^{1}$ Eliza $^{2}$, Windi Elsia Haria ${ }^{3}$ \\ ${ }^{1,2,3}$ STIKes Nan Tongga Lubuk Alung ${ }^{1}$ \\ Email : yuliamnur17@gmail.com
}

Accepted: 20/02/2020

Published: 14/03/2020

\begin{abstract}
Dengue fever is an infectious disease by a virus that is transmitted through the bite of the Aedes aegypti mosquito. Mild infections only cause patches on the body and mild flu symptoms. Dengue hemorrhagic fever is caused by dengue virus. Dengue hemorrhagic fever is not transmitted through human contact with humans. Predisposing factors encompass public knowledge and attitudes towards health, traditions and community trust in matters relating to health, the value system adopted by the community, education level, socio-economic level, and so on. This type of research is analytic descriptive with cross sectional method. The population in this study were patients who visited the health center totaling 25 people and a sample of 25 people taken by total sampling. Data collection tools using a questionnaire. Data analysis was carried out univariately and bivariately. The results of this study indicate that $64.0 \%$ of respondents have low knowledge, $52.0 \%$ of respondents have negative attitudes, $56.0 \%$ of respondents have bad actions, and $56.0 \%$ of respondents have low DHF prevention. There is a significant relationship between knowledge (0.013), attitude (0.003), action (0.010) with the prevention of DHF with $p$ value 0.05. It is expected that respondents will maintain environmental hygiene by increasing their knowledge, attitudes and actions in preventing DHF by participating in DHF prevention activities.
\end{abstract}

Keywords: action, attitude, dengue prevention, knowledge

\begin{abstract}
Abstrak
Penyakit demam berdarah adalah penyakit infeksi oleh virus yang ditularkan melalui gigitan nyamuk Aedes aegypti. Infeksi yang ringan hanya menimbulkan bercak-bercak pada badan dan gejala flu ringan. Demam berdarah dengue disebabkan oleh virus dengue. Virus dengue sebagai penyebab demam berdarah hanya dapat ditularkan melalui nyamuk. Faktor predisposisi mencangkup pengetahuan dan sikap masyarakat terhadap kesehatan, tradisi dan kepercayaan masyarakat terhadap hal-hal yang berkaitan dengan kesehatan, sistem nilai yang dianut masyarakat, tingkat pendidikan, tingkat sosial-ekonomi, dan sebagainya. Jenis penelitian ini adalah deskriptif analitik dengan metode cross sectional. Populasi dalam penelitian ini adalah pasien yang berkunjung kepuskesmas yang berjumlah 25 orang dan sampel sebanyak 25 orang yang diambil dengan cara total sampling. Alat pengumpulan data memakai kuesioner. Analisa data dilakukan secara univariat dan bivariat. Hasil penelitian ini menunjukkan bahwa 64,0\% responden memiliki pengetahuan rendah, $52,0 \%$ responden memiliki sikap negatif, 56,0\% responden memiliki tindakan tidak baik, dan 56,0\% responden memiliki pencegahan DBD rendah. Terdapat hubungan yang bermakna antara pengetahuan (0.013), sikap (0.003), tindakan (0.010) dengan pencegahan DBD dengan $\mathrm{p}$ value 0.05 . Diharapkan kepada responden untuk menjaga kebersihan lingkungan dengan meningkatkan pengetahuan, sikap serta tindakan dalam pencegahan DBD dengan banyak mengikuti kegiatan pencegahan DBD.
\end{abstract}

Kata Kunci : pencegahan DBD, pengetahuan, sikap, tindakan 


\section{PENDAHULUAN}

Demam Berdarah Dengue (DBD) merupakan salah satu masalah kesehatan masyarakat di Indonesia, dikarenakan jumlah penderita dan luas daerah penyebarannya semakin bertambah seiring dengan meningkatnya mobilitas dan kepadatan penduduk (Kemenkes RI, 2010). Demam berdarah ditemukan hampir di seluruh dunia terutama negara tropik dan subtropik (Ariani, 2016), yang dalam kurun waktu 5 tahun terakhir jumlah kasus dan daerah terjangkit terus meningkat dan menyebar luas serta sering menimbulkan kejadian luar biasa/KLB (Depkes RI, 2017). Kejadian demam berdarah dapat berpotensi menimbulkan dampak sosial yang berupa keresahan masyarakat karena perjalanan penyakitnya yang cepat dan dapat menyebabkan kematian dalam waktu singkat, serta dampak ekonomi yaitu meningkatnya anggaran belanja negara untuk pengobatan penyakit demam berdarah (Afrian, dkk, 2016)

Data WHO (2015) memperkirakan 2,5 miliar atau $40 \%$ populasi didunia berisiko terhadap penyakit DBD terutama yang tinggal di daerah perkotaan di negara tropis dan subtropis. Saat ini juga diperkirakan ada 390 juta infeksi dengue yang terjadi di seluruh dunia setiap tahun.

Demam Berdarah Dengue (DBD) adalah penyakit febris akut, seringkali disertai dengan sakit kepala, nyeri tulang atau sendi dan otot, ruam dan leucopenia sebagai gejalanya. Demam berdarah dengue ditandai oleh empat manifestasi klinis utama yaitu : demam tinggi, fenomena hemorragic, sering dengan dengan hepatomegali dan pada kasus berat tandatanda kegagalan sirkulasi. Pasien ini dapat mengalami shock hipovolemik yang diakibatkan oleh kebocoran plasma. Shock ini disebut Sindrom Shock Dengue (SSD) dan dapat menjadi fatal (WHO, 2015).

Penyakit demam berdarah merupakan salah satu masalah kesehatan masyarakat di Indonesia. Penyakit DBD merupakan salah satu masalah kesehatan masyarakat Indonesia yang jumlah penderitanya cenderung meningkat dan menyebar semakin luas. Direktorat Jendral Pemberantasan Penyakit Menular dan Penyehatan Lingkungan menyatakan penyakit DBD adalah penyakit infeksi oleh virus dengue yang ditularkan melalui gigitan nyamuk aedes aegypti, dengan ciri demam tinggi mendadak disertai manifestasi perdarahan dan bertendensi menimbulkan renjatan (shock) dan kematian (Depkes RI, 2010).

Kasus DBD di Indonesia menurut Dirjen Pengendalian Penyakit dan Penyehatan Lingkungan (P2PL) Kementerian Kesehatan RI (2017), mengatakan bahwa pada tiga bulan terakhir tahun 2016, jumlah kasus DBD cenderung menurun dengan rentang 8.487 kasus dengan jumlah kematian 108 orang (Kemenkes RI). Berdasarkan data yang yang dirilis oleh Kementerian Kesehatan, jumlah kasus DBD per 29 januari 2019 mencapai 13.683 dengan jumlah kematian 133 jiwa (Profil Kemenkes RI).

Penyebaran DBD secara pesat dikarenakan virus dengue semakin mudah dan banyak menulari manusia. Selain itu juga didukung oleh : 1) meningkatnya jumlah penduduk di dalam kota. 2) sikap dan pengetahuan masyarakat tentang pencegahan penyakit yang masih kurang.2 Meningkatnya DBD dalam 15 tahun terakhir di duga disebabkan oleh beberapa faktor penting antara lain 1) Tidak 
terencana dan tidak terkontrolnya urbanisasi serta pertumbuhan penduduk yang mengakibatkan padatnya penduduk yang tinggal di pusat-pusat kota tropis dengan kondisi higiene yang kurang baik, 2) Kurang efektifnya program pengawasan terhadap nyamuk vektor, perubahan gaya hidup dan makin memburuknya sistem air minum sehingga menghasilkan perluasan dan peningkatan densitas nyamuk vektor utama.3 Faktor risiko lainnya terhadap penularan DBD adalah kemiskinan yang mengakibatkan orang tidak mempunyai kemampuan untuk menyediakan rumah yang layak dan sehat, pasokan air minum dan pembuangan sampah yang benar (Chandra, dkk, 2010).

Penyakit DBD disebabkan oleh virus dengue dari kelompok Arbovirus B, yaitu Arthropod-Bornevirus atau yang disebarkan Arthropoda. Vektor utama penyakit DBD adalah nyamuk yang menjadi penyakit infeksi saat menggigit manusia yang sedang sakit dan viremia (terdapat virus dalam darahnya) (Husni, 2018).

Virus berkembang dalam tubuh nyamuk selama 8-10 hari terutama dalam kelenjar air liurnya, dan jika nyamuk menggigit orang lain maka virus dengue akan dipindahkan melalui air liurnya. Virus ini akan berkembang selama 4-6 hari dalam tubuh manusia dan orang tersebut akan mengalami sakit demam berdarah dengue. Virus dengue memperbanyak diri dalam tubuh manusia dan berada dalam darah selama 1 minggu (Mau, 2014).

Virus ditularkan bersama dengan air liur nyamuk masuk ketubuh orang sehat sehingga orang tersebut menderita demam berdarah. Kondisi ini dikenal dengan transmisi horisontal. Penularan Virus Den tanpa melalui gigitan nyamuk vektor terjadi transmisi vetikal atau disebut dengan transovarial transmision. Penularan tersebut virus Den diturunkan dari induk nyamuk infektif melalui telur kepada nyamuk generasi berikutnya melalui telur (Rohani, (2008) dan Masitha, 2013).

Penularan virus dengue terjadi melalui gigitan nyamuk yang termasuk subgenus Stegomya yaitu nyamuk Aedes aegypti dan Ae. albopictus sebagai vektor primer dan Ae. polynesiensis, Ae.scutellaris serta Ae (Finlaya) niveus sebagai vektor sekunder, selain itu juga terjadi penularan transexsual dari nyamuk jantan ke nyamuk betina melalui perkawinan serta penularan transovarial dari induk nyamuk ke keturunannya (WHO, . Ada penularan virus melalui transfusi darah (Tampyah,2008). Dari beberapa cara penularan virus dengue, yang paling tinggi adalah penularan melalui gigitan nyamuk Ae. aegypti. (Gubler, 2002) Masa inkubasi ekstrinsik (di dalam tubuh nyamuk) berlangsung sekitar 8-10 hari, sedangkan inkubasi intrinsik (dalam tubuh manusia) berkisar antara 4-6 hari dan diikuti dengan respon imun (Kristina, 2004).

Penyakit DBD masih merupakan salah satu masalah kesehatan masyarakat yang utama di Indonesia. Jumlah penderita dan luas daerah penyebarannya semakin bertambah seiring dengan meningkatnya mobilitas dan kepadatan penduduk. Di Indonesia Demam Berdarah pertama kali ditemukan di kota Surabaya pada tahun 1968, dimana sebanyak 58 orang terinfeksi dan 24 orang diantaranya meninggal dunia (Angka Kematian (AK) : 41,3\%). Dan sejak saat itu, penyakit ini menyebar luas ke seluruh Indonesia (Achmadi, 2010).

Penanggulangan demam berdarah dengue salah satunya dengan metode pengontrolan atau pengendalian vektornya. Metode penanggulangan DBD adalah dengan cara Pemberantasan Sarang Nyamuk (PSN) yang digalakkan 
pemerintah, pengolahan sampah padat yang baik, dan perbaikan desainrumah, memberikan bubuk abate (temephos) pada tempat-tempat hidup dan berkembangbiak genetic nyamuk misalnya pada penampungan air seperti, gentong air, vas bunga, kolam dan sebagainya.

Informasi masalah kesehatan khususnya tentang DBD akan mempengaruhi tindakan masyarakat dibidang kesehatan. Sebagai mana kita ketahui perilaku manusia sangat erat kaitannya dengan masalah kesehatan, baik kesehatan pribadi maupun kesehatan masyarakat. Perilaku masyarakat disini mencakup pengetahuan, sikap dan tindakan masyarakat supaya terhindar dari suatu penyakit. Selain itu dukungan petugas kesehatan juga merupakan faktor lain yang dapat mempengaruhi perilaku masyarakat dalam upaya pencegahan demam berdarah dengue (DBD). Dukungan petugas kesehatan setempat berguna pada saat seseorang menghadapi kenyataan bahwa perilaku sehat yang baru itu merupakan hal yang penting. Begitu juga petugas kesehatan dapat mempengaruhi perilaku masyarakat dengan cara menyampaikan informasi terhadap tindakan pencegahan demam berdarah dengue (Notoatmodjo, 2012).

Beberapa kebijakan yang telah dikeluarkan oleh pemerintah untuk menekan angka kejadian penyakit DBD dan akibat yang ditimbulkannya, diantaranya memerintahkan pihak rumah sakit maupun puskesmas untuk tidak menolak melakukan pengasapan/fogging. Dan yang biasanya dilakukan oleh petugas kesehatan dari dinas kesehatan atau Puskesmas terdekat dan melakukan 3M yaitu, Menguras, Mengubur dan Menutup, sehingga diperlukan peran aktif dari keluarga dan dukungan petugas kesehatan (Depkes RI, 2018).

Di Indonesia tahun 2018 dengan jumlah penderita DBD sebanyak 112,511 orang dan kasus yang meninggal sebanyak 871 orang dan tahun 2019 tercatat penderita DBD di 34 provinsi di Indonesia sebanyak 71.668 orang, dan 541 diantaranya meninggal dunia (Depkes RI, 2017).

Berdasarkan data Dinas Kesehatan Kota Padang, di Provinsi Sumatera Barat pada tahun 2016menyatakan jumlah penderita Demam Berdarah Dengue sebanyak 911 kasus diantaranya 15 orang meninggal dunia, sedangkan pada tahun 2017 mengalami penurunan,jumlah penderita Demam Berdarah Dengue sebanyak 608 kasus dan 5 yang meninggal dunia,dan kemudian pada tahun 2018-1019 sebanyak 2.203 kasus dengan 10 orang yang meninggal dunia (Dinkes ,Profil Kesehatan Sumbar, 2017).

Jumlah kasus DBD pada tahun 2017 berdasarkan data Dinas Kesehatan Kabupaten Padang Pariaman adalah 172 kasus. Sedangkan pada tahun 2018-2019, terjadi peningkatan kasus DBD yaitu 350 kasus. Untuk kasus terbanyak terdapat pada wilayah Puskesmas sintuk dengan 18 kasus diikuti Puskesmas sungai sarik 17 kasus, Puskesmas Lubuk Alung 14 kasus dan Puskesmas Pasar usang 25 kasus.

Menurut penelitian yang dilakukan oleh Nurfitriani, (2016) mengatakan bahwa dari 75 responden mempunyai pengetahuan tinggi yang baik pencegahan DBD sebanyak $43(57,3 \%)$ dan sebanyak 32 $(42,7 \%)$ responden yang kurangbaik pencegahan DBD, selanjutnyadari 19 responden mempunyai pengetahuan rendah yang baik pencegahan DBD sebanyak 1 
$(5,3 \%)$ dan sebanyak $18 \quad(94,7 \%)$ beresponden kurang baik pencegahan DBD.

Jumlah DBD di Puskesmas Pasar Usang sebanyak 25 kasus diantaranya 15orang meninggal. Survei awal yang peneliti lakukanpada April 2019 kepada 10 keluarga di Wilayah Pasar Usang Tanjung Basung diketahuibahwa 4 keluarga tidak mengetahui tentang penyakit DBD dan cara mencegah penyakit demam berdarah dan tindakan apa saja yang dilakukan untuk memberantas penyakit demam berdarah dengue sedangkan 6 orang keluarga sudah mengetahui tentang penyakit demam berdarah dengue, tetapi tidak tahu cara pencegahannya. Dan dari 10 orang tersebut diketahui bahwa 3 orang diantaranya memiliki jenjang pendidikan SD dan SMP, dan hanya 7 orang yang melanjut jenjang pendidikan ke SMA. Akan tetapi pengetahuan masyarakat tentang pencegahan DBD masih kurang.

Selain itu masyarakat juga tidak pernah melakukan kegiatan menguras bak mandi sekali seminggu, mereka juga jarang membersihkan lingkungan sekitar rumah yang banyak sampah. Sehingga mengakibatkan rendahnya pecegahan DBD karena keluarga malas mengapresiasikan cara pencegahan demam berdarah dengue dalam kehidupan sehari-hari.

\section{METODE PENELITIAN}

Jenis penelitian yang digunakan yaitu deskriptifanalitik dengan pendekatan cross sectional study dimana pengukuran terhadap variabel bebas dengan variabel terikat dilakukan dalam waktu persamaan (Notoatmodjo 2013).

Penelitian ini dilaksanakan di Tanjung Basung Wilayah kerja Puskesmas Pasar Usang, waktu penelitiannya yaitu bulan Maret sampai juli 2019. Populasi dari penelitian ini adalah seluruh pasien yang dirawat di Puskesmas Pasar Usang, ratarata pasien yang berkunjung dengan DBD 25 sorang. Sedangkan sampel pada penelitian ini adalah total sampling yaitu semua pasien yang datang berkunjung selama penelitian di Puskesmas Pasar Usang.

Metode analisa data yang digunakan adalah Analisa Univariat, analisa univariat hasilnya di tampilkan dalam bentuk distribusi frekuensi antara variabel bebas dengan variabel terikat. Tujuan untuk menjelaskan karakteristik masing-masing variabel yang teliti. Dan analisis bivariat yang dilakukan dengan uji statistik untuk mengetahui hubungan antara variabel terikat memakai rumus derajat kemaknaan signifikan 0,05 .

\section{HASIL DAN PEMBAHASAN}

\section{A. Pengetahuan Responden}

Pengetahuan adalah merupakan hasil "Tahu", dan ini terjadi setelah orang melakukan penginderaan terhadap suatu objek tertentu. Penginderaan terjadi melalui panca indra manusia, yakni : indera penglihatan, pendengaran, penciuman, rasa dan raba. Pengetahuan yang dimiliki sangat penting untuk terbentuknya sikap dan tindakan (Notoatmodjo, 2012). Berdasarkan hasil penelitian yang telah dilakukan didapatkan bahwa lebih dari separuh responden memiliki tingkat pengetahuan rendah, yaitu sebesar $64.0 \%$ dan hanya $36.0 \%$ responden yang memiliki pengetahuan tinggi.

Berdasarkan penelitian yang telah dilakukan maka diperoleh hasil tentang pengetahuan responden tentang tentang pencegahan DBD adalah sebagai berikut : 
Tabel. 1. Distribusi Frekuensi Pengetahuan Responden tentang Pencegahan Demam Berdarah

\begin{tabular}{lcc}
\hline Pengetahuan & $\mathrm{f}$ & $\%$ \\
\hline Tinggi & 10 & 36.0 \\
Rendah & 15 & 64.0 \\
Total & 25 & 100 \\
\hline
\end{tabular}

Rendahnya pengetahuan responden disebabkan karena rendahnya tingkat pendidikan akan membuat kurangnya pengetahuan serta lambatnya penerimaan informasi saat petugas memberikan penyuluhan kesehatan mengenai pencegahan DBD. Selain disebabkan karena kurangnya kesadaran masyarakat akan pentingnya menjaga kebersihan lingkungan sekitar tempat tinggalnya.

Pendidikan merupakan salah satu faktor pendukung terhadap pengetahuan seseorang. Dimana menurut Notoatmodjo (2012) bahwa seseorang yang berpendidikan tinggi biasanya lebih mudah memahami sesuatu dibandingkan dengan orang yang memiliki pendidikan yang rendah, serta mereka berpikir secara logis sesuai dengan tingkat jenjang pendidikan yang mereka miliki.

Pengetahuan merupakan hasil dari tahu, dan ini terjadi setelah seseorang melakukan pengindraan terhadap objek tertentu. Pengindraan terjadi melalui pancaindra manusia, yakni penglihatan, pendengaran, penghirup, perasa, dan peraba. Tetapi sebagian besar pengetahuan manusia diperoleh melalui mata dan telinga. Pengetahuan atau kognitif merupakan domain yang sangat penting dalam mebantu tindakan seseorang (overt behaviour). Perilaku didasari oleh pengetahuan akan lebih bertahan lama daripada perilaku yang tidak didasari pengetahuan (Penelitian Rogers (1974), dalam Sunaryo (2004 : 5), dalam Hasmi (2015).

Menurut Nila (2015) dan Heri (2010) dalam penelitiannya menunjukkan bahwa pengetahuan menunjukkan pengaruh yang signifikan terhadap perilaku seseorang dalam melakukan pemberantasan sarang nyamuk demam berdarah dengue.

Penelitian ini sejalan dengan pendapat Machfoedz dan Suryani (2016) yang memyatakan orang yang pengetahuannya bertambah sehingga muncul kesadaran dalam diri untuk bertindak dalam hidup sehat secara baik. Menerapkan perilaku sehat yaitu pencegahan penyakit DBD, merupakan langkah ampu untuk menangkal penyakit, namun dalam praktiknya, penerapan ini yang kesannya sederhana tidak selalu mudah dilakukan terutama bagi responden yang tidak terbiasa, kurangnya pengetahuan dan sedikitnya kesadaran berperilaku hidup sehat.

\section{B. Sikap Responden}

Berdasarkan penelitian yang telah dilakukan maka diperoleh hasil adalah sebagai berikut :

Tabel. 2 Distribusi Frekuensi Sikap Responden Tentang Pencegahan Demam Berdarah

\begin{tabular}{lcc}
\hline Sikap & f & $\%$ \\
Responden & & \\
\hline Positif & 12 & 48.0 \\
Negatif & 13 & 52.0 \\
Total & 25 & 100 \\
\hline
\end{tabular}

Dari tabel 5.2 ditunjukkan bahwa lebih dari separuh responden memiliki sikap yang negatif terhadap upaya pencegahan DBD sebesar $(52.0 \%)$ dan hanya $48.0 \%$ ) responden yang memiliki sikap positif. 
Pengukuran sikap dapat dilakukan secara langsung dan juga tidak langsung. Secara langsung dapat dinyatakan bagaimana pendapat atau pertanyaan respon terhadap suatu objek. Orang lain berperilaku bertentangan dengan sikapnya, dan bisa juga merubah sikapnya sesudah yang bersangkutan merubah tindakannya. Namun secara tidak mutlak dapat dikatakan bahwa perubahan sikap merupakan loncatan untuk terjadinya peribahan perilaku (Marini, 2010).

Sikap merupakan reaksi atau respon seseorang yang masih tertutup terhadap suatu stimulus atau obyek. Seorang ahli psikologi social, Newcomb, menyatakan bahwa sikap merupakan kesiapan atau kesediaan untuk bertindak, dan bukan merupakan pelaksanaan motif tertentu. Sikap bukan merupakan suatu tindakan atau aktivitas, akan tetapi adalah "pre-disposisi" tindakan atau perilaku. Pengukuran sikap dapat dilakukan secara langsung atau tidak langsung dengan menanyakan bagaimana pendapat atau pernyataan responden terhadap suatu objek (Notoatmodjo, 2007 cit Tyrsa, 2015).

Penelitian ini sejalan dengan penelitian yang dilakukan oleh Rahmaditia (2011) bahwa terdapat hubungan antara sikap responden terhadap tindakan pencegahan DBD, dimana memiliki nilai $p<0.05$ yaitu $p=0.007$. Hasil penelitian yang dilakukan oleh Macpal (2015), bahwa terdapat hubungan antara sikap dengan tindakan pencegahan DBD pada masyarakat batu kota lingkungan III kota Manado. Nilai $\mathrm{p}=0,01(\mathrm{p}<0.05)$.

Penelitian ini sejalan dengan hasil penelitian Montung (2012) menunjukkan bahwa terdapat hubungan yang bermakna antara sikap dengan tindakan pencegahan DBD pada masyarakat di wilayah kerja Puskesmas Kolongan Minahasa Utara.
Sikap responden merupakan respon yang sudah bersifat terbuka dan telah tampak dalam kehidupan nyata sehingga tercermin dalam tindakan pencegahan yang mereka lakukan secara lebih baik sesuai dengan sikap positif mereka terhadap upaya pencegahan itu sendiri (Montung, 2012).

$$
\text { Menurut Cambell dalam }
$$

Notoatmodjo, (2016) mengatakan bahwa sikap merupakan suatu sindroma atau kumpulan gejalah dalam merespon stimulus atau objek, sehingga sikap melibatkan pikiran, perasaan, perhatian serta gejala kejiwaan yang lain. Dalam hal ini responden masih belum mengetahui masalah-masalah tentang pencegahan DBD sehingga responden masih banyak yang bersikap negatif terhadap upaya pencegahan DBD.

$$
\text { Notoatmodjo, (2015) juga }
$$
menyatakan bahwa sikap merupakan reaksi atau respon yang masih tertutup dari seseorang terhadap suatu stimulus atau objek manifestasi dari sikap tidak dapat dilihat, tetapi hanya dapat ditafsirkan terlebih dahulu dari perilaku yang tertutup. Selain itu Deddy Maulana (2013) dan Nila (2015) dalam penelitiannya menambahkan bahwa sikap memiliki pengaruh yang signifikan terhadap perilaku seseorang dalam melakukan pemberantasan sarang nyamuk demam berdarah dengue.

Menurut asumsi peneliti kurangnya sikap positif responden dalam penelitian ini dapat disebabkan karena responden tidak memiliki pengetahuan yang memadai. Karena daya tangkap responden yang kurang terhadap materi penyuluhan kesehatan tentang pencegahan DBD yang telah diberikan oleh pihak Puskesma Pasar Usang. Selain itu juga dapat disebabkan karena kesadaran akan pentingnya 
melakukan pencegahan DBD masih kurang walaupun telah menerima penyuluhan tentang pencegahan DBD.

\section{Tindakan Responden}

Berdasarkan tabel 3. menunjukkan bahwa lebih dari separuh responden memiliki tindakan tidak baik sebanyak $(78,4 \%)$ responden, sedangkan tindakan baik sebanyak $(27,3 \%)$ responden.

Tabel. 3 Distribusi frekuensi Tindakan Responden terhadap Pencegahan DBD

\begin{tabular}{lcc}
\hline Tindakan & $\mathrm{f}$ & $\%$ \\
\hline Baik & 11 & 44.0 \\
Kurang & 14 & 56.0 \\
Baik & & \\
$\quad$ Total & 25 & 100 \\
\hline
\end{tabular}

Hasil penelitian ini sejalan dengan penelitian yang dilakukan oleh Seryobudi (2015)bahwa terdapat hubungan antara tindakan responden terhadap pencegahan $\mathrm{DBD}$, dimana memiliki nilai $\mathrm{p}<0.05$ yaitu $\mathrm{p}=0.012$ menunjukkan partisipasi masyarakat dalam tindakan terhadap pencegahan DBD.

Hal ini senada dengan penelitian yang dilakukan oleh Suhardino (2014) tentang analisi faktor perilaku masyarakat terhadap kejadian DBD di Kelurahan Helvetia tengah, medan hasil penelitian menunjukkan ada hubungan tindakan dengan kejadian DBD dengan nilai $\mathrm{p}=$
0.001, $(\mathrm{p}<0,05), \mathrm{OR}=4,48$ dan CI $95 \%=$ 1,822-11, 051.

Partisipasi masyarakat merupakan proses panjang dan memerlukan ketekunan, kesabaran dan upaya dalam memberikan pemahaman dan motivasi kepada individu, kelompok, masyarakat, bahkan pejabat secara berkesinambungan. Program yang melibatkan masyarakat adalah mengajak masyarakat mau dan mampu melakukan 3 M Plus atau PSN dilingkungan mereka. Namun karena masyarakat sangat heterogen dalam tingkat pendidikan, pemahaman dan latar belakangnya sehingga belum mampu mandiri dalam pelaksanaannya.

Menurut asumsi peneliti hasil ini menunjukkan bahwa ada hubungan yang bermakna antara tindakan dengan pencegahan DBD di Tanjung Basung Wilayah Puskesmas Pasar Usang. Hal ini dapat dikatakan bahwa jika responden memiliki tindakan tidak baik, maka akan mengakibatkan terjadinya penyakit DBD karena kurangnya tindakan dalam melakukan pencegahan DBD.

\section{Hubungan Pengetahuan dengan Pencegahan DBD}

Berdasarkan penelitian yang telah dilakukan maka diperoleh hasil sebagai berikut :

Tabel. 4. Hubungan Pengetahuan dengan Pencegahan DBD

\begin{tabular}{|c|c|c|c|c|c|c|c|c|}
\hline \multirow{3}{*}{$\begin{array}{c}\text { Tingkat } \\
\text { Pengetahuan }\end{array}$} & \multicolumn{4}{|c|}{ Pencegahan DBD } & & & \multirow{3}{*}{$\frac{\mathrm{p} \text { value }}{0,013}$} & \multirow{3}{*}{$\frac{\mathrm{OR}}{0,075}$} \\
\hline & \multicolumn{2}{|c|}{ Baik } & \multicolumn{2}{|c|}{ Kurang Baik } & \multicolumn{2}{|c|}{ Total } & & \\
\hline & $\mathrm{f}$ & $\%$ & $\mathrm{f}$ & $\%$ & $\mathrm{f}$ & $\%$ & & \\
\hline Tinggi & 1 & $11.1 \%$ & 8 & 88.9 & 9 & 100 & & \\
\hline Rendah & 10 & 62.5 & 6 & 37.5 & 16 & 100 & & \\
\hline Total & 11 & 44.0 & 14 & 56.0 & 25 & 100 & & \\
\hline
\end{tabular}


Berdasarkan tabel 4. dapat diketahui bahwa dari 25 responden, yang memiliki pengetahuan yang tinggi sebanyak 9 responden (36.0\%), sedangkan yang memiliki pengetahuan rendah sebanyak 16 responden $(64.0 \%)$ responden. Di dapatkan $p$ value $=0,05<0,013$, artinya ada hubungan yang bermakna antara pengetahuan responden dengan pencegahan DBD di Tanjung Basung Wilayah kerja Puskesmas Pasar Usang.

Hasil penelitian ini sejalan dengan yang dilakukan oleh Yusida (2015) menyatakan bahwa ada hubungan yang bermakna antara pendidikan dengan pencegahan $\mathrm{DBD}$ dengan nilai $\mathrm{p}$ value $=$ $0,042<0,05$. Hasil penelitian yang dilakukan oleh Heraswati (2016), membuktikan bahwa terdapat hubungan antara tingkat pendidikan dengan tindakan kepala keluarga menggerakkan anggota keluarga dalam pencegahan penyakit DBD.

Pengetahuan atau kognitif merupakan dominan yang sangat penting bagi terbentuknya tindakan seseorang (overt Behavior). Karena dari pengalaman dan

\section{E. Hubungan Sikap dengan Pencegahan DBD} berikut :

Berdasarkan penelitian yang telah dilakukan maka diperoleh hasil adalah sebagai Tabel 5. Hubungan Sikap Responden dengan Pencegahan DBD

\begin{tabular}{|c|c|c|c|c|c|c|c|c|}
\hline \multirow{3}{*}{ Sikap } & \multicolumn{4}{|c|}{ Pencegahan DBD } & \multirow{2}{*}{\multicolumn{2}{|c|}{ Total }} & \multirow[b]{2}{*}{$\mathrm{p}$ value } & \multirow[b]{2}{*}{ OR } \\
\hline & \multicolumn{2}{|c|}{ Tinggi } & \multicolumn{2}{|c|}{ Rendah } & & & & \\
\hline & $\mathrm{f}$ & $\%$ & $\mathrm{f}$ & $\%$ & $\mathrm{f}$ & $\%$ & 0,003 & 0,061 \\
\hline Positif & 9 & 75.0 & 3 & 25.0 & 12 & 100 & & \\
\hline Negatif & 2 & 15.4 & 11 & 84.6 & 13 & 100 & & \\
\hline Total & 11 & 44.0 & 14 & 56.0 & 25 & 100 & & \\
\hline \begin{tabular}{l}
\multicolumn{2}{c}{ Berdas } \\
hwa dari \\
kap negat \\
banyak 13
\end{tabular} & & & ih & \multicolumn{5}{|c|}{$\begin{array}{l}\text { yang memiliki sikap positif sebanyak } 1 \\
\text { responden }(48.0 \%) \text { responden. Selain it } \\
\text { hasil } p \text { value }=0,05<0,003 \text { artinya ad } \\
\text { hubungan yang bermakna antara sika } \\
\text { dengan pencegahan DBD di Tanjun }\end{array}$} \\
\hline
\end{tabular}


Basung Wilayah puskesmas Pasar Usang. Hasil ini menunjukkan bahwa sikap responden yang negatif tentang pencegahan DBD merupakan salah satu faktor terjadinya DBD.

Pentingnya pendidikan dan sikap masyarakat dengan pola hidup sehat agar terhindar DBD. Pengurasan TPA seminggu sekali akan memberi efek positif bagi kehidupan sehat masyarakat untuk menghindari tingginya angka kejadian DBD (Husni, dkk, 2018).

Menurut penelitian Tyrsa, (2015) terdapat hubungan yang signifikan antara pengetahuan dengan tindakan PSN DBD serta terdapat hubungan yang signifikan antara sikap dengan tindakan PSN DBD. Dimana sikap merupakan variable yang paling dominan. Hal senada juga sama dengan penelitian yang dilakukan Rahmaditia (2011) bahwa terdapat hubungan antara sikap responden terhadap tindakan pencegahan DBD diman memiliki nilai $\mathrm{p}<0,05$ yaitu $\mathrm{p}=0,007$. Hasil penelitian ini sama dengan penelitian
Rosiana (2015) yang menyatakan bahwa terdapat hubungan yang bermakna antara sikap dengan penegahan DBD dengan nilai $p$ value $=0,008<0,05$.

Berdasarkan teori dari Calhoun dan Acocella (2016) yang menyatakan bahwa sikap adalah sesuatu yang melekat pada keyakinan-keyakinan dan perasaanperasaan terhadap suatu objek dan menunjukkan hasil bahwa terdapat hubungan yang signifikan antara pengetahuan keluarga dengan pencegahan DBD.

Hasil penelitian ini ternyata ada hubungan yang bermakna antara sikap dengan pencegahan DBD. Dari hal ini menurut asumsi peneliti ternyata masih ada yang memiliki sikap negatif terhadap pencegahan DBD, dimana sikap negatif ini dapat berdampak pada terjadinya penyakit DBD. Karena meskipun tinggi pengetahuannya tapi sikapnya rendah, itu tidak akan membantu dalam melakukan pencegahan DBD.

\section{F. Hubungan tindakan dengan pencegahan DBD}

Tabel 6. Hubungan Tindakan Responden terhadap Pencegahan DBD

\begin{tabular}{lcccccccc}
\hline \multirow{3}{*}{ Tindakan } & \multicolumn{4}{c}{ Pencegahan DBD } & & & \\
& \multicolumn{2}{c}{ Tinggi } & \multicolumn{2}{c}{ Rendah } & & Total & p value & OR \\
\cline { 2 - 7 } & \multicolumn{1}{c}{ f } & $\%$ & $\mathrm{f}$ & $\%$ & $\mathrm{f}$ & $\%$ & 0,010 & 9.778 \\
Positif & 8 & 72.7 & 3 & 27.3 & 11 & 100 & & \\
Negatif & 3 & 21.4 & 11 & 78.6 & 14 & 100 & & \\
Total & 11 & 44.0 & 14 & 56.0 & 25 & 100 & & \\
\hline
\end{tabular}

Berdasarkan tabel 6. dapat diketahui pencegahan DBD di Tanjung Basung bahwa dari 25 responden, yang memiliki Wilayah Puskesmas Pasar Usang.

Tindakan merupakan respon internal tindakan tidak baik sebanyak 14 responden (56.0\%), sedangkan yang memiliki setelah adanya pemikiran, tanggapan, sikap tindakan baik sebanyak 11 responden (44.0\%) responden, yang diperoleh hasil $\mathrm{p}$ value $=0,05<0,010$ artinya ada hubungan yang bermakna antara tindakan dengan batin dan wawasan. Seseorang yang memiliki tingkat pendidikan formal yang tinggi memiliki tingkat pengetahuan dan wawasan yang lebih baik dan luas serta 
memiliki kepribadian dan sikap yang lebih dewasa. Wawasan dan pemikiran yang lebih luas di bidang kesehatan akan mempengaruhi perilaku individu dalam menyikapi suatu masalah. Pendidikan yang baik dapat memotivasi, memberi contoh dan mendorong anggota keluarga untuk melakukan pencegahan penyakit DBD (Notoatmodjo, 2010).

Hasil penelitian ini ternyata ada hubungan yang bermakna antara tindakan dengan pencegahan. Dari hal ini menurut asumsi peneliti yang memiliki tindakan tidak baik akan berdampak pada pencegahan DBD, karena jika tidak ada tindakan maka pencegahan DBD tidak akan dilakukan, karena jika responden memiliki pengetahuan yang tinggi tetapi memiliki tindakan yang tidak baik, maka pecegahan DBD akan menurun.

\section{SIMPULAN}

Dari hasil penelitian dapat disimpulkan bahwa lebih dari separuh $(64.0 \%)$ responden yang memiliki pengetahuan rendah, lebih dari separuh $(52.0 \%)$ responden yang memiliki sikap negative, lebih dari separuh $(56.0 \%)$ responden memiliki tindakan tidak baik, terdapat hubungan pengetahuan dengan pencegahan DBD di Tanjung Basung Wilayah Puskesmas Pasar Usang dengan nilai $\mathrm{p}$ value $=0,013$, . terdapat hubungan sikap dengan pencegahan DBD di Tanjung Basung Wilayah Puskesmas Pasar Usang dengan nilai $\mathrm{p}$ value $=0,003$, terdapat hubungan tindakan dengan pencegahan DBD di Tanjung basung Wilayah puskesmas pasar Usang dengan nilai $p$ value $=0,010$.

\section{UCAPAN TERIMA KASIH}

Ucapan terima kasih penulis sampaiakan kepada : bapak/ibu petugas Puskesmas Pasar Usang yang telah membantu selama penulis melaksanakan penelitian, teman- teman, serta semua pihak yang terlibat yang membantu selesainya penelitian ini.

\section{DAFTAR PUSTAKA}

Afrian, dkk. (2016). Pengetahuan Model Motivasi Jumarior Juru Pemantau Jentik Junior Dalam Perilaku Psn Pemberantasan Sarang Nyamuk Aedes Aegypti Berbasis Integrasi Model Lawrance Green Dan Mc. Clelleand. Jurnal Ilmiah Kesehatan, Vol.9,No.1, 129-137

Ariani, A.P, 2017. Demam Berdarah Dengue DBD. Yogyakarta : Nuha Medika

Achmadi, U. F. (2010). Manajemen Demam Berdarah Berbasis Wilayah. Buletin Jendela Epidemiologi, Vol. 2, Agustus 2010.

Candra A. (2010). Demam Berdarah Dengue : Epidemiologi, Patogenesis, dan Faktor Risiko Penularan. Jurnal Aspirator, Vol.2 No.2, Hal:110- 119

Depkes, RI. (2010). Pencegahan dan Pemberantasan Demam Berdarah Dengue di Indonesia, Direktorat Jendral PPM \& PL. Jakarta

Depkes, RI. (2012). Pencegahan dan Pemberantasan Demam Berdarah Dengue di Indonesia, Ditjen PPM \& PL. Jakarta

Depkes, RI. (2017).Pencegahan dan Pemberantasan Demam Berdarah Dengue di Indonesia,Ditjen PPM \& PL. Jakarta

Depkes, RI. (2018).Pemberantasan Nyamuk Penular Demam Berdarah Dengue di Indonesia, Ditjen PPM \& PL. Jakarta

Husni, Jumal, Isfanda, dan Y. Rahmayanti. (2018). Studi Kasus Demam Berdarah Dengue (DBD) terhadap Keberadaan 
Vektor Aedes aegypti di Gampong Ateuk Pahlawan Kota Banda Aceh. Jurnal Penelitian Kesehatan, Vol.5 No. 1,26-35

Indah, R, Nurjannah, Dahlia dan Hermawati, D. (2011). Studi Pengetahuan, Sikap dan Perilaku Masyarakat Aceh Dalam Pencegahan Demam Berdarah Dengue (KAP study on dengue prevention in aceh. Prosiding Seminar Hasil Penelitian Kebencanaan TDMRC-Unsyiah, Banda Aceh. 13 - 19 April 2011.

Irianto Koes. (2014). Parasitologi Berbagai Penyakit yang Mempengaruhi Kesehatan Manusia. Bandung. CV. Ydhrma Widia

Kementrian Kesehatan. (2017). Dirjen Pengendalian Pemyakit dan Penyehatan Kesehatan Lingkungan (P2PL) : Jakarta

Kunoli, Firdaus J. (2014). Pengantar Epidemiologi Penyakit Menular. Jakarta : CV. Trans Info Media

Macpal, S. D. (2015). Hubungan Antara Pengetahuan dan Sikap dengan Tindakan Pencegahan Penyakit Demam Berdarah Dengue. Jurnal Ilmiah Farmasi, Vol. 5 No. 1

Mau, F, dan Ira I.P. Bule Sopi. (2014). Demam Berdarah Dengue dan Transmisi Transovarial Virus Dengue pada Aedes spp. Jurnal Penyakit Bersumber Binatang, Vol. 2, No. 1, Hal: 1-7

Misnadiarly. (2014). Demam Berdarah Dengue. Jakarta: Pustaka Obor Populer

Montung, D. (2012). Hubungan Antara Karakteristik Individu, Pengetahuan, Sikap Dengan Tindakan Masyarakat Dalam Pencegahan Demam Berdarah Dengue Di Wilayah Kerja Puskesmas Kolongan Minahasa Utara. (Tesis), Manado: Universitas Sam Ratulangi.

Notoatmodjo, S. (2010). Konsep Perilaku Kesehatan. Promosi Kesehatan teori dan aplikasi Edisi revisi 2010. Jakarta: Rineka Cipta, hal. 43-64

Notoatmodjo, Soekidjo. (2013). Metode Penelitian Kesehatan. Jakarta: PT. Rineka Cipta

Notoatmodjo, Soekidjo. (2015). Pendidikan dan Perilaku Kesehatan. Jakarta: PT. Rineka Cipta

Notoatmodjo, Soekidjo. (2016). Promosi Kesehatan dan Ilmu Perilaku. Jakarta: PT. Rineka Cipta

Rahmaditia, T. (2011). Hubungan Pengetahuan Dan Sikap Ibu Terhadap Tindakan Pencegahan Demam Berdarah Dengue Pada Anak (Di Wilayah Kerja Puskesmas Tlogosari Wetan Kota Semarang). (Laporan Akhir Hasil Penelitian Karya Tulis Ilmiah), Semarang: Fakultas Kedokteran Universitas Diponegoro.

Rohani A, Zamree I, Joseph RT dan Lee HL. (2008). Persistency of transovarial dengue virus in aedes aegepti (linn). Southeast Asian. Journal Trop Med Public Health. Vol.39, No. 5:813-816

Masitha, MR. Hendri Astuty. (2013). Kepadatan dan Penyebaran Aedes aegypti Setelah Penyuluhan DBD di Kelurahan Paseban, Jakarta Pusat. eJKI Vol. 1, No. 1.

Soedarto. (2012). Demam Berdarah Dengue hemorhagic fever. Jakarta: Sugeng Seto

Tyrsa, C.N, Monintja. (2015). Hubungan Antara Karakteristik Individu, Pengetahuan Dan Sikap Dengan Tindakan PSN DBD Masyarakat Kelurahan Malalayang I Kecamatan Malalayang Kota Manado. JIKMU, Vol. 5, No. 2 b April 2015

WHO. (2015). Demam Berdarah Dengue. Kedokteran. Jakarta : EGC

WHO. (2009). Dengue: Guidlines for Diagnosis, Treatment, Prevention and Control. New Edition. Geneva: World Health Organization. 
Tambyah PA, Koay ESC, Poon MLM, Lin RVTP, Ong BKC. (2008). Dengue Hemorrhagic Fever Transmitted by Blood Transfusion. The England Journal of Medicine, Vol. 359: p. 1526-7.

Gubler DJ. (2002). Epidemic Dengue Hemorrhagic Fever as a Public Health, Sosial and Economic Problem in Tha 21st Century. Journal Trends Microbiol.; Vol. 10: p. 100-13.

Kristina, Ismaniah, Wulandari L. (2004). Kajian Masalah Kesehatan : Demam Berdarah Dengue. In: Balitbangkes, editor.: Tri Djoko Wahono. 